\title{
A study of austenitization of SG iron
}

\author{
UMA BATRA*, PANKAJ TANDON and KULBIR KAUR \\ Metallurgical Engineering Department, Punjab Engineering College, Chandigarh 160 012, India
}

MS received 25 November 1999; revised 24 July 2000

\begin{abstract}
Austenitization process of three SG irons with varying compositions and as cast matrix microstructure has been studied at three austenitization temperatures of 850,900 and $950 \mathrm{C}$ for different time periods. Microstructure, hardness and X-ray diffraction have been used to reveal the nature of dependence of the process on austenitization temperature, time and as cast structure. The optimum austenitization time is maximum for ferritic and minimum for pearlitic matrix.
\end{abstract}

Keywords. Austenitization; austempering; austempered ductile iron.

\section{Introduction}

Austempered ductile irons (ADI) have been gaining popularity as a potential replacement material for steel in a number of applications because of their outstanding mechanical properties (Moore et al 1987; Grech 1993). ADI is produced by (i) austenitization of the iron in the temperature range $850-950 \mathrm{C}$ for sufficient time (60-90 min depending on the section thickness), (ii) quenching to an austempering temperature between 250 and $425 \mathrm{C}$, and holding it for an appropriate length of time to permit isothermal transformation, and (iii) air cooling or water quenching to room temperature. During austenitization, the matrix of cast structure consisting of ferrite or ferrite and pearlite or pearlite transforms to homogenized austenite, $\gamma_{0}$. Its carbon content depends on the austenitization temperature, $T_{\gamma}$ (Darwish et al 1993). Austempering reaction occurs in two stages. In the first stage, austenite matrix transforms to bainitic ferrite, $\alpha$, by rejection of carbon by bainitic ferrite into rest austenite to form high carbon austenite, $\gamma_{s}$. In second stage, the high carbon austenite, $\gamma_{s}$, formed in stage I, transforms to bainitic ferrite and carbide. If the carbon content of austenite, $\gamma_{s}$, formed in stage I is high enough then it will be retained during cooling. However if the carbon content of $\gamma_{\mathrm{s}}$ is not enough then it will transform to martensite during cooling. The carbon content of austenite formed in stage I depends on the carbon content of initial austenite, $\gamma_{0}$, formed during austenitization and amount of carbon rejected into austenite during bainitic transformation in stage I of austempering. The driving force for stage I of austempering increases with the decrease of carbon content of initial austenite, $\gamma_{0}$ (Darwish et al 1993). It can be seen from above discussion that carbon

\footnotetext{
*Author for correspondence
}

content of initial austenite, $\gamma_{0}$, is most important element in the transformation of austenite. Accordingly a study of the carbon behaviour during austenitization is essential for precise control of the structure and properties in ADIs.

In the present work austenitization processes have been studied in the ferritic, ferritic plus pearlitic and pearlitic ductile irons. Microstructural, hardness and X-ray diffraction data have been presented to reveal the nature of dependence of the austenitization on temperature, time and cast structure. Three austenitization temperatures of 850,900 and $950 \mathrm{C}$ have been used for three different alloys.

\section{Experimental}

The composition of the ductile irons used in present study are given in table 1 . Wafer specimens of size $15 \times 15 \times 10 \mathrm{~mm}$ were sectioned from the castings. The specimens were austenitized in cast iron chips bed at various austenitization temperatures for various time periods and subsequently quenched in water. Hardness measurements were made using a standard vickers pyramid hardness tester with a $20 \mathrm{~kg}$ load. Using vickers microhardness tester with $100 \mathrm{~g}$ load, microhardness testing was carried out. Each measurement of macro and microhardness represent the average of ten indentations. Neophot-2 was used for metallographic study. The change in carbon content of the matrix austenite (martensite) was measured by $\mathrm{X}$-ray diffraction using $\mathrm{CuK} \alpha$ radiation at $40 \mathrm{kV}$ and $20 \mathrm{~mA}$ in water quenched samples. A Phillips X-ray diffractometer was used with software to scan the angular $2 \theta$ ranges from 37 to $52^{\circ}$. In each pattern martensite 101/110-twin reflection was readily identified. The scan of $2 \theta$ was repeated three times for each sample in order to obtain a good statistical 
average of the angular position $2 \theta$ of (101)/(110) planes. A general relationship between the carbon content of the matrix austenite (wt.\%) $\mathrm{C}_{\gamma}^{0}$, Bragg angles of the $\left(h_{1} k_{1}\right.$ $\left.l_{1}\right) /\left(h_{2} k_{2} l_{2}\right)$ twin reflections ${ }^{\theta}\left(h_{1} k_{1} l_{1}\right)$ and ${ }^{\theta}\left(h_{2} k_{2} l_{2}\right)$ and their Miller indices were used to calculate $\mathrm{C}_{\gamma}^{0}$. This relationship was established using the following procedure. For the martensite structure,

$$
\sin ^{2} \theta_{h k l}=\frac{\lambda^{2}}{4}\left(\frac{h^{2}+k^{2}}{a_{\alpha^{\prime}}^{2}}+\frac{l^{2}}{c_{\alpha^{\prime}}^{2}}\right),
$$

where $\lambda$ is the wavelength of the incident radiation, and $a_{\alpha^{\prime}}$ and $c_{\alpha^{\prime}}$ are the lattice parameters of the bct structure which are given as functions of the carbon content (Cullity 1956).

$$
\begin{aligned}
& c_{\alpha^{\prime}}=2 \cdot 861+0 \cdot 116\left(C_{\gamma}^{0}\right), \\
& a_{\alpha^{\prime}}=2 \cdot 861-0.013\left(C_{\gamma}^{0}\right) .
\end{aligned}
$$

It is assumed that $\mathrm{Si}$ and the alloying elements do not affect the lattice parameters $a_{\alpha^{\prime}}$ and $c_{\alpha^{\prime}}$ of the martensite.

Simple rearrangement of (1) to (3) leads to the following expression for the $101 / 110$ peaks:

$$
C_{\gamma}^{0}=\frac{\lambda\left[\frac{1}{2 \sin ^{2} \theta_{101}-\sin ^{2} \theta_{110}}\right]^{1 / 2}-5 \cdot 722}{0 \cdot 232} .
$$

The austenite carbon content can be calculated from accurate measurement of the angular position $2 \theta$ of the martensite twin planes.

\begin{tabular}{|c|c|c|c|c|c|}
\hline Alloy & $\begin{array}{c}\text { Equivalent } \\
\text { ASTM } \\
\text { grade }\end{array}$ & $\begin{array}{c}\text { Nodule } \\
\text { count } \\
\left(\mathrm{mm}^{-2}\right)\end{array}$ & $\begin{array}{l}\text { Ferrite } \\
\text { (vol. \%) }\end{array}$ & $\begin{array}{l}\text { Pearlite } \\
\text { (vol. \%) }\end{array}$ & $\begin{array}{c}\text { Hardness } \\
\text { (Hv20) }\end{array}$ \\
\hline $\mathrm{Ni}-\mathrm{Mo}$ iron & $450 / 10$ & 100 & 99 & 1 & 188 \\
\hline $\mathrm{Cu}$-iron I & $500 / 7$ & 150 & 20 & 80 & 245 \\
\hline $\mathrm{Cu}$-iron II & $600 / 3$ & 250 & 5 & 95 & 260 \\
\hline
\end{tabular}

Table 1. Compositions of irons used (weight \%).

\begin{tabular}{lccc}
\hline Element & Ni-Mo iron & Cu-iron I & Cu-iron II \\
\hline $\mathrm{C}$ & 3.43 & 3.60 & 3.48 \\
$\mathrm{Si}$ & 3.02 & $2 \cdot 20$ & 2.028 \\
$\mathrm{Mn}$ & 0.287 & 0.40 & 0.22 \\
$\mathrm{P}$ & 0.016 & 0.02 & 0.05 \\
$\mathrm{~S}$ & 0.007 & 0.003 & 0.004 \\
$\mathrm{Cr}$ & - & 0.017 & 0.05 \\
$\mathrm{Mo}$ & 0.43 & 0.06 & 0.33 \\
$\mathrm{Cu}$ & - & 0.40 & 0.60 \\
$\mathrm{Ni}$ & 1.160 & 0.07 & 0.016 \\
$\mathrm{Ti}$ & - & - & 0.04 \\
$\mathrm{Mg}$ & 0.12 & 0.04 & 0.04 \\
\hline
\end{tabular}

Table 2. Microstructural characteristics of as cast iron.

\section{Results and discussion}

\subsection{Microstructural characteristics of as cast iron}

The microstructural characteristics of the three irons in the as cast condition are summarized in table 2 . The micrographs of these irons in as cast condition are shown in figure 1 .

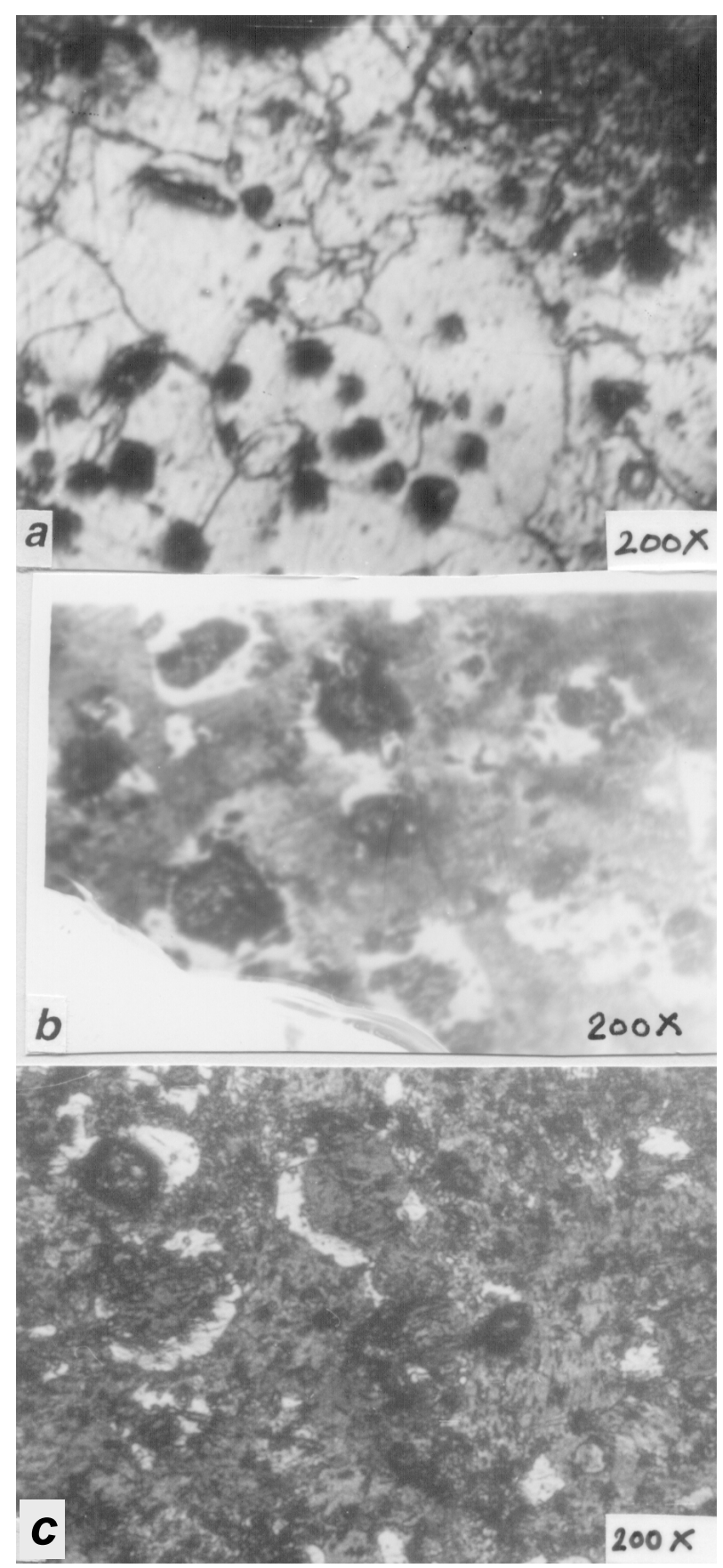

Figure 1. Microstructure of cast ductile iron a. Ni-Mo, b. $\mathrm{Cu}$-iron $\mathrm{I}$ and c. $\mathrm{Cu}$-iron II. 


\subsection{Microstructural changes during austenitization}

Figure 2 shows $\mathrm{Ni}-\mathrm{Mo}$ iron (with ferrite matrix) quenched after austenitization, at $900 \mathrm{C}$ for various time periods. Figure 2a shows no transformation to austenite even after $10 \mathrm{~min}$ of austenitization. The matrix consists of ferrite grains. Austenite has nucleated at ferrite/graphite interfaces after austenitization for $15 \mathrm{~min}$ (figure $2 \mathrm{~b}$ ). A fully martensitic structure with nonuniform carbon content is observed after $50 \mathrm{~min}$ of austenitization (figure 2c). After $90 \mathrm{~min}$ uniform martensite structure is observed and there is no further change in microstructure (figure 2d). $\mathrm{Cu}$-iron I (with ferrite + pearlite matrix) was austenitized at $900 \mathrm{C}$ for different time periods and quenched. The structure after 2 min of austenitization shows graphite nodule surrounded by ferrite, which was present in the cast condition. The remaining dark areas are martensite that has formed from austenite on quenching (figure 3a). Extensive transformation to austenite has occurred in the pearlitic regions of the cast structure after 5 min of austenitization (figure $3 \mathrm{~b}$ ). There is more of martensite and less of ferrite. Longer austenitization times result in less ferrite content (figure 3c). Most of the ferrite has disappeared from the microstructure after $40 \mathrm{~min}$. The structure consists of martensite, with a mixture of blue and orange colour in this time period but the amount of blue martensite decreases with the increase in the austenitization time. After $70 \mathrm{~min}$ there is only orange colour of martensite throughout the matrix, which implies that austenite has become saturated with carbon by this time. This is also supported by the results of hardness measurements, which show that there is no change in hardness after $70 \mathrm{~min}$ (figure 3d). Figure 4 shows the microstructures for quenched samples of $\mathrm{Cu}$-iron II with fully pearlitic matrix. Austenitization has occurred in all the regions after $2 \mathrm{~min}$ but the uniform martensite structure is observed only after $60 \mathrm{~min}$.

\subsection{Kinetics of austenitization}

3.3a Hardness study: The study of austenitization kinetics was carried out by using hardness of quenched samples to represent the amount of martensite for three austenitization temperatures 850, 900 and 950C for three ductile irons of compositions given in table 1 . Figure 5 shows the change of hardness of these samples with austenitization time. There is no change in the hardness in the first few minutes. Then there is sharp increase in hardness followed by a slow increase in hardness. Finally the maximum hardness is achieved and it remains
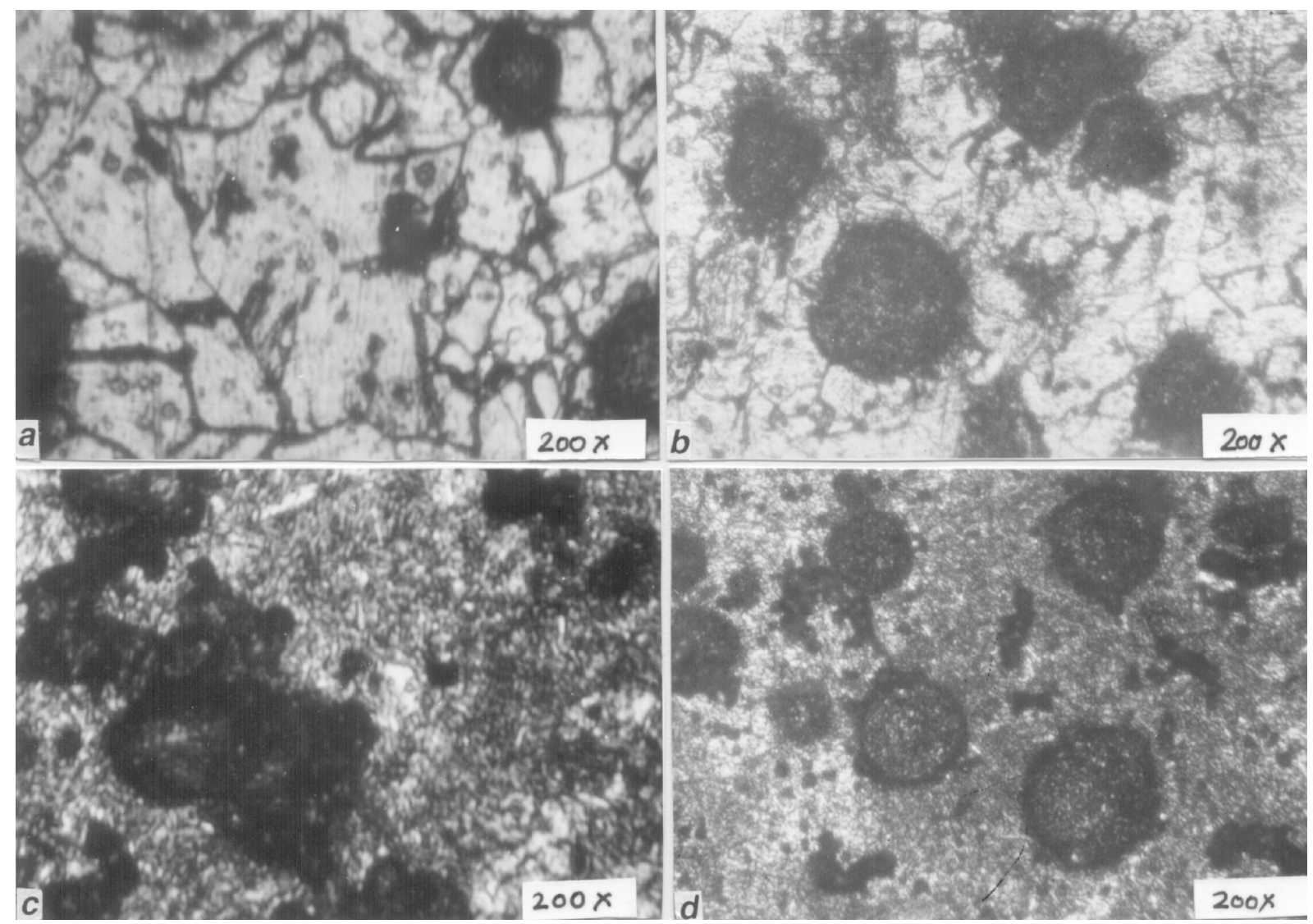

Figure 2. Microstructural changes during austenitization of $\mathrm{Ni}-\mathrm{Mo}$ iron at $900^{\circ} \mathrm{C}$ for a. $10 \mathrm{~min}$, b. $15 \mathrm{~min}$, c. $50 \mathrm{~min}$ and d. $90 \mathrm{~min}$. 

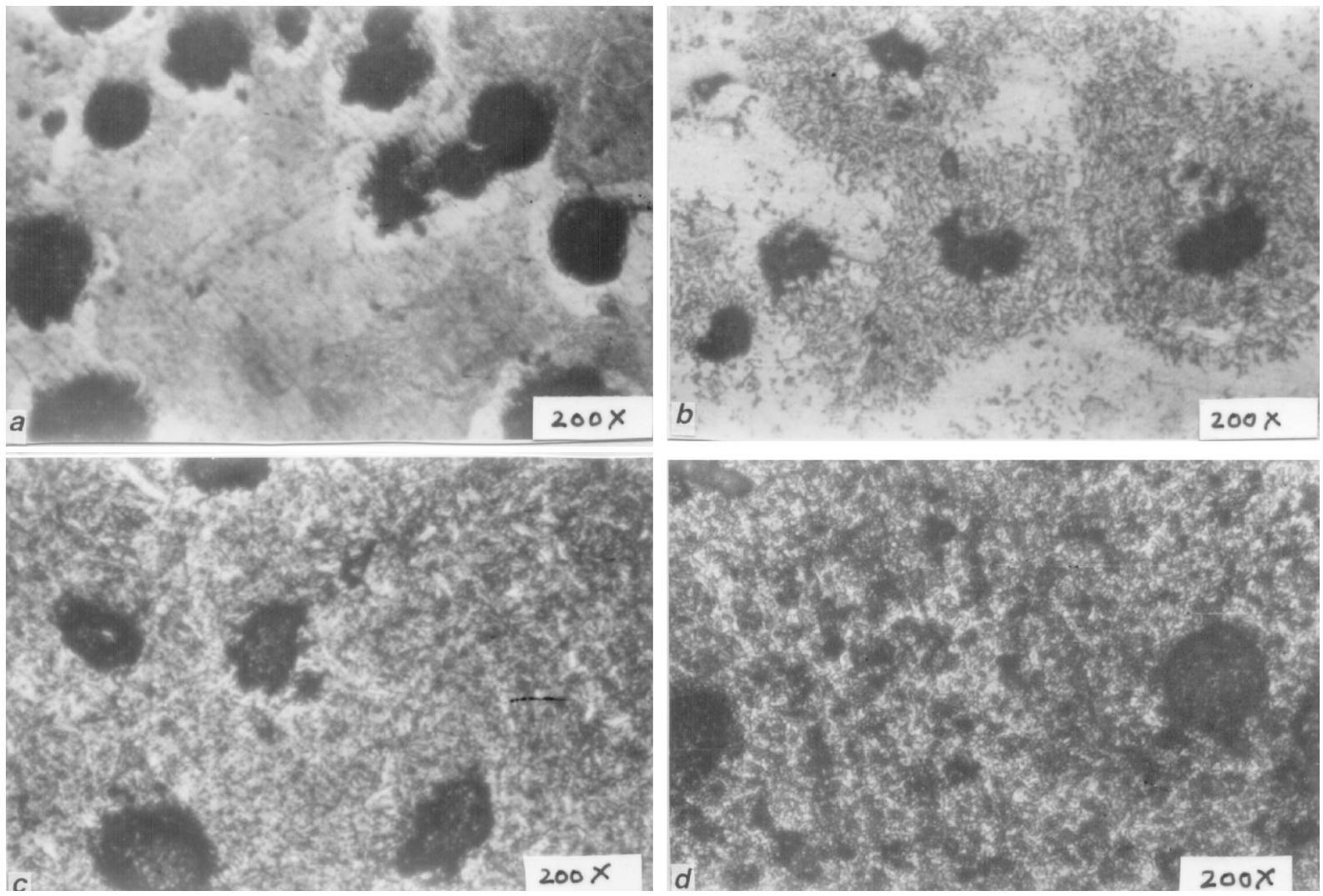

Figure 3. Microstructural changes during austenitization of $\mathrm{Cu}-$-iron I at $900^{\circ} \mathrm{C}$ for a. $2 \mathrm{~min}$, b. $5 \mathrm{~min}$, c. $40 \mathrm{~min}$ and d. $70 \mathrm{~min}$.

constant thereafter. The increase in hardness starts at 15 , 2 and $1 \mathrm{~min}$ for $\mathrm{Ni}-\mathrm{Mo}$ iron, $\mathrm{Cu}$-iron $\mathrm{I}$ and $\mathrm{Cu}$-iron II respectively. This time is taken as, $t_{\mathrm{i}}$, when austenitization begins. Before this time no change in microstructure has been observed. The time, $t_{\mathrm{i}}$, is maximum for $\mathrm{Ni}-\mathrm{Mo}$ iron with ferrite matrix and it decreases significantly with increase in amount of pearlite in the cast structure. The austenitization occurs by nucleation and growth mechanism. Nucleation occurs at ferrite/cementite or ferrite/ graphite interface. In the ferritic ductile iron ferrite/ graphite is the only interface available. In case of ferritic + pearlitic matrix both types of interfaces and in case of pearlitic ductile iron ferrite/cementite interface is available. The influence of $\%$ pearlite on the time required for the initiation of austenite formation indicate that the nucleation at ferrite/cementite interface is preferred over that at ferrite/graphite interface. For a particular alloy, the increase in austenitization temperature decreases $t_{\mathrm{i}}$. Further increase in hardness, after time $t_{\mathrm{i}}$, is due to increase in the amount of austenite (from microstructure) and carbon dissolution in austenite. In Ni-Mo iron, austenite boundary moves faster in ferrite but carbon diffuses to austenite from nodule only. The diffusion distance is long. In $\mathrm{Cu}$-iron $\mathrm{I}$ and $\mathrm{Cu}$-iron II, the austenite boundary moves slowly but the carbon diffuses from cementite lamellae of pearlite to austenite through cementite/austenite interface additionally and here the diffusion distance for carbon diffusion is less. The carbon enrichment of austenite is faster in these. As the pearlite content and austenitization temperature increase, the maximum hardness of austenite increases, because of the increase in solubility of carbon in austenite, the time to reach maximum hardness also decreases because of faster kinetics of austenitization. Slow increase in hardness in the next stage corresponds to homogenization of carbon in austenite. Homogenization occurs faster in austenite produced from the cast pearlite structure than in austenite produced from ferrite. The results of microhardness study between two nodules for $\mathrm{Cu}$-iron II is shown in figure 6 for various time periods of austenitization. The microhardness study (as well as the microstructures explained earlier) reveal that uniform microhardness value and uniform microstructure between the two nodules are observed corresponding to 90,70 and $60 \mathrm{~min}$ for $\mathrm{Ni}-\mathrm{Mo}$ iron, $\mathrm{Cu}-$ iron $\mathrm{I}$ and $\mathrm{Cu}$-iron II respectively. Before these time periods the hardness is not uniform between two nodules. This time period is taken as $t_{\mathrm{f}}$ i.e. completion of austenitization process (when hardness reaches a maximum value and remains constant after this time). The time $t_{\mathrm{f}}-$ $t_{\mathrm{i}}$ is the time during which austenite formation, carbon 
dissolution and its homogenization takes place. The time $t_{\mathrm{i}}$ and $t_{\mathrm{f}}-t_{\mathrm{i}}$ are each plotted as a function of austenitization temperature in figure 7 . The time $t_{\mathrm{i}}$ as well as $t_{\mathrm{f}}-t_{\mathrm{i}}$ are maximum for ferritic iron and it decreases significantly as the pearlite content of the cast structure increases and as the silicon content decreases.

3.3b Carbon content of matrix austenite: Figure 8 shows that the carbon content of prior austenite (martensite) increases sharply first and then there is slow increase and finally it becomes constant. In Ni-Mo iron the carbon content increased steadily until it approached a maximum and constant carbon content at $90 \mathrm{~min}$. In $\mathrm{Cu}$-iron II the concentration of austenite increases sharply from the early stage of austenite formation and maximum and constant carbon content is achieved at $60 \mathrm{~min}$. Also the maximum carbon content of austenite increases with increase in pearlite content of the cast structure. The following equation has been used to calculate the equilibrium content of austenite (Darwish et al 1993):

$$
C_{\gamma}^{0}=\frac{T_{\gamma}}{420}-0 \cdot 17(\% \mathrm{Si})-0 \cdot 95
$$
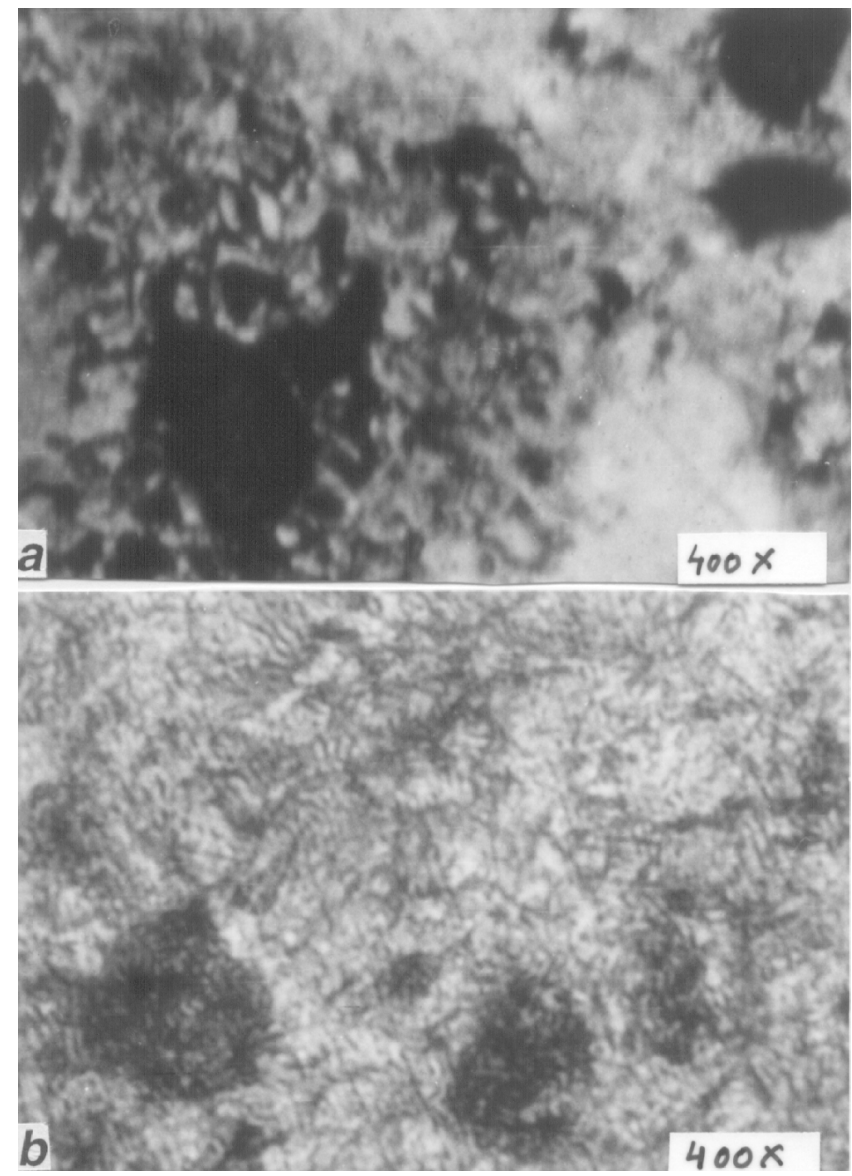

Figure 4. Microstructural changes during austenitization of $\mathrm{Cu}$-iron II at $900^{\circ} \mathrm{C}$ for a. $2 \mathrm{~min}$ and b. $60 \mathrm{~min}$.

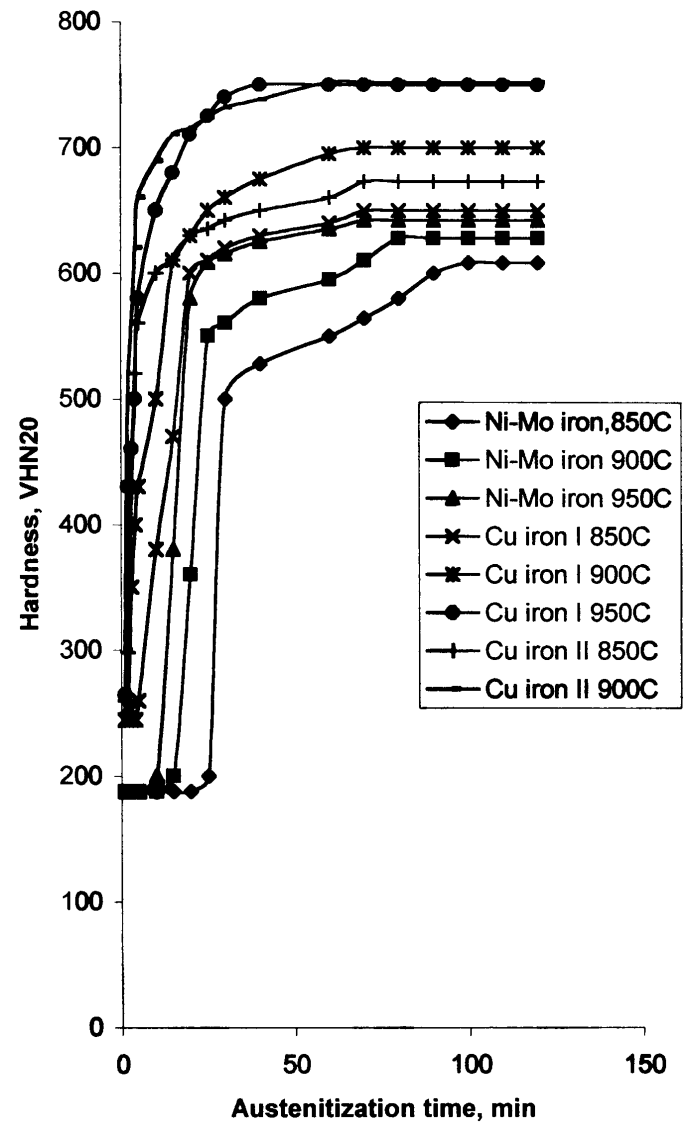

Figure 5. Variation of hardness with austenitization time and temperature for all the three types of irons.

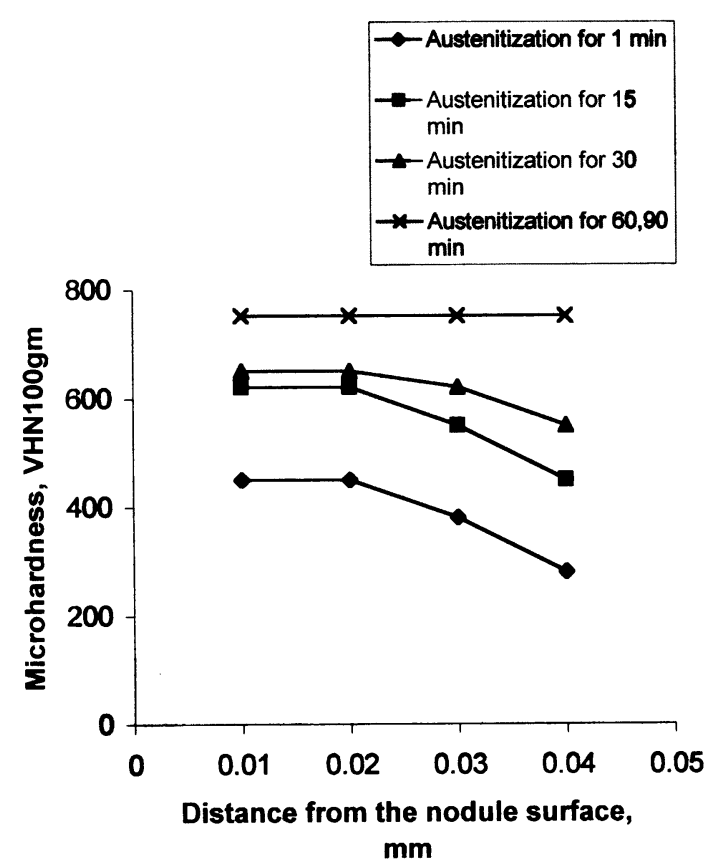

Figure 6. Variation of microhardness between the two nodules during austenitization of $\mathrm{Cu}$-iron II at $900^{\circ} \mathrm{C}$ for various time periods. 


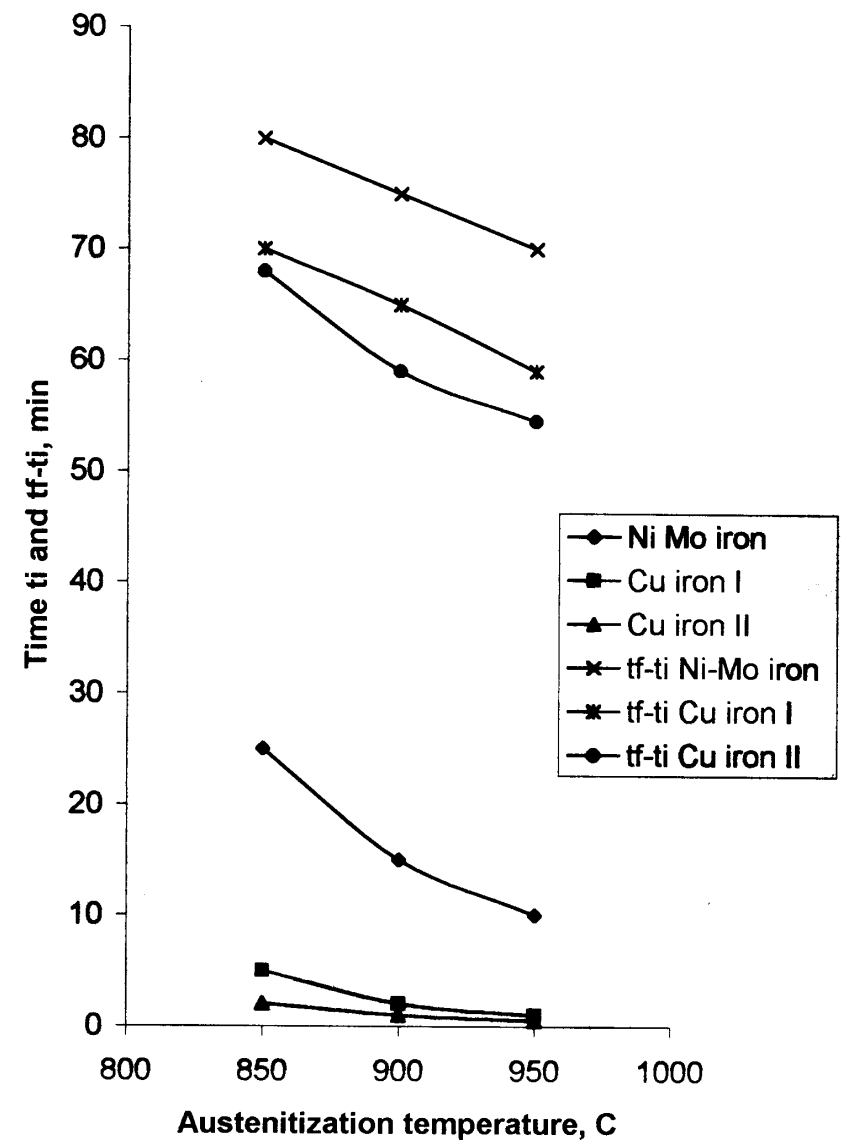

Figure 7. Variation of time $t_{\mathrm{i}}$ and time period $t_{\mathrm{f}}-t_{\mathrm{i}}$ with austenitization temperature for all the three types of irons.

$C_{\gamma}^{0}$ calculated from this equation is in agreement with the maximum carbon content of austenite estimated experimentally by X-ray diffraction for three alloys at 900C.

\section{Conclusions}

The importance of the austenitization parameters i.e. temperature, time and the cast structure has been studied on ferritic, ferritic plus pearlitic and pearlitic ductile irons. Austenitization is promoted significantly when there is a high pearlitic content in the as cast matrix

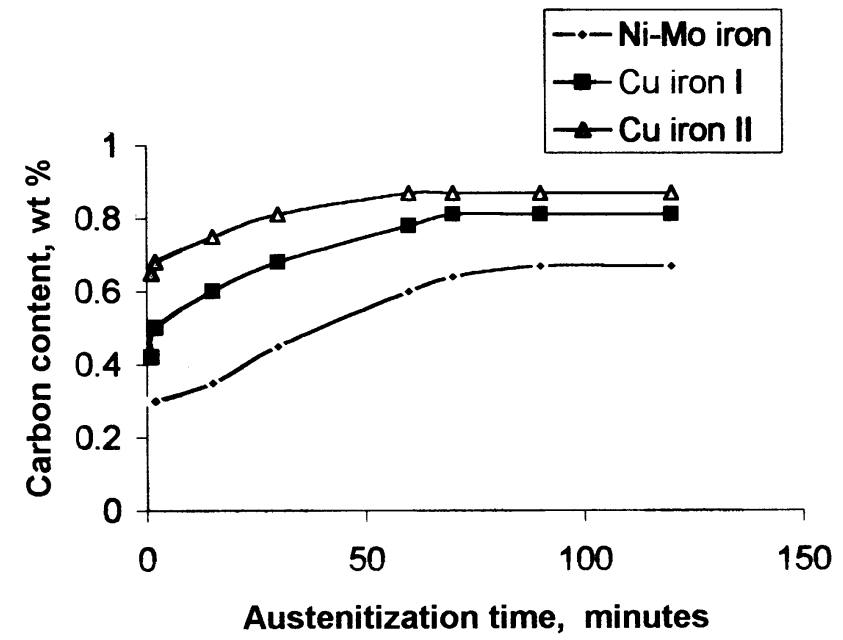

Figure 8. Variation of carbon content of matrix austenite $\left(C_{\gamma}\right)$ with austenitization time for all the three types of irons.

structure. Increasing the austenitization temperature accelerates the austenitization kinetics and increases the carbon solubility in the austenite phase. The optimum austenitization temperature and time is that at which austenite with maximum and uniform carbon has been achieved. At the austenitization temperature of $900 \mathrm{C}$, the optimum austenitization time for Ni-Mo iron is $90 \mathrm{~min}$, for $\mathrm{Cu}$-iron $\mathrm{I} 70 \mathrm{~min}$ and for $\mathrm{Cu}$-iron II $60 \mathrm{~min}$. The equilibrium carbon content of austenite is $0.67 \%$ for $\mathrm{Ni}-\mathrm{Mo}$ iron, $0.81 \%$ for $\mathrm{Cu}$-iron $\mathrm{I}$ and $0.87 \%$ for $\mathrm{Cu}-$ iron II.

\section{References}

Cullity B D 1956 Elements of X-ray diffraction (Reading, MA: Addison Wesley Publishing Company, Inc.)

Darwish N et al 1993 Mater. Sci. Technol. 91572

Grech M 1993 An update on austempered ductile iron, International conference on mechanical behaviour of ductile iron and other cast metals, Kilakyushu, Japan p. 18

Gundlach R B et al 1984 1st International conference on austempered ductile irons (Chicago, Illinois, Ohio: ASM) p.1 Moore P A et al 1987 AFS Trans. 764 